\title{
OPTIMIZATION OF A COMPTON DIRECT-CHARGE DETECTOR FOR MONITORING HIGH-ENERGY BREMSSTRAHLUNG RADIATION
}

\author{
V.I. Nikiforov, I.N. Shlyakhov, V.A. Shevchenko, A.Eh. Tenishev, V.L. Uvarov \\ National Science Center "Kharkov Institute of Physics and Technology", Kharkiv, Ukraine \\ E-mail: uvarov@kipt.kharkov.ua
}

The conditions of application of a Compton direct-charge detector (DCD) for monitoring of intensity of the highenergy bremsstrahlung (X-ray) radiation are studied. A method is described for calculation of characteristics of the secondary e,X-radiation at exit of an electron accelerator, and also for providing the conditions of the electronic equilibrium. By means of computer simulation, the processes of charge generation in a DCD monitor comprising two plates of different thickness from various metals are analyzed. On the basis of the obtained results, the requirements imposed on DCD composition for providing the maximum of its sensitivity are formulated. It is shown, that within the suggested DCD geometry, the monitor sensitivity reveals a weak dependence on the atomic number of its material at $Z>29$, and also on the end-point energy of $X$-rays in the span of $20 \ldots 100 \mathrm{MeV}$.

PACS: 07.85.Fv

\section{INTRODUCTION}

Activation direct-charge detectors (DCD) are used in atomic energetics for intra-reactor measurement of neutron flux [1]. In the work [2], the possibility was shown to apply a detector charged with the flux of the Compton electrons (a Compton DCD) for monitoring of highenergy bremsstrahlung radiation. Such the sources of radiation with end-point energy of the photon spectrum of up to $100 \mathrm{MeV}$ and average power of tens $\mathrm{kW}$ are lately developed for various photonuclear technologies (nonreactor isotope production, electron accelerator driven control of sub-critical assemblies etc. - see e.g. [3, 4]).

A detector, described in the Ref. [2], consists of two metal plates of different thickness fixed on an isolator and separated with a vacuum gap. When exposure to $\gamma$ radiation, the flux of secondary particles is generated in the plates. As a result, the one plate (an emitter) acquires the positive charge, when the other plate (a collector) the negative one. The electric current arising in an external circuit between the collector and emitter is proportional to the intensity of gammas.

In the work, the optimization of DCD characteristics is conducted on the basis of analysis of the charge generation process in the sensor's plates for monitoring the high-power X-ray radiation within a wide span of the photon energy.

\section{FORMATION OF ELECTRONIC EQUILIBRIUM}

Braking radiation is obtained by acting with electron beam on a target-converter maid from a high- $Z$ material (Ta, W, Au and oth.). The value of the coefficient of the beam energy $E_{b}$ transformation into energy of the X-ray radiation $E_{x}, E_{x} / E_{b}$, depends on the electron energy $E_{0}$, the material and thickness of the converter. The maximum yield of the secondary radiation is reached when the converter thickness makes about half of the electron range in its material. As a result, a part of the primary beam electrons leaves the converter besides the braking radiation. At the same time, correct measurement of high-energy photon flux is only possible providing the conditions of electronic equilibrium in the secondary radiation. [5]. Those conditions are reached by placement of an additional absorber-filter of primary beam electrons.
It was shown in the work [6], that the contribution of each element of the accelerator exit devices into the state of the secondary radiation is convenient to describe in unified form via the thickness of that element expressed in the units of the range of the electrons with energy $E_{0}$ in its material (stopping thickness unit or stu). The sum of all elements of the tract of the secondary radiation formation, defined in such a way, makes its stopping length. As a result, it was established, that in the wide range of the atomic number of the materials $(Z=7 \ldots 73)$ and electron energy $\mathrm{E}_{0}=5 \ldots 100 \mathrm{MeV}$ the condition of maximum of the conversion coefficient $\mathrm{E}_{\mathrm{x}} / \mathrm{E}_{\mathrm{b}}$ is provided at a tract stopping length of about $0.5 \mathrm{stu}$ (a high- $Z$ material) to of about 0.7 stu (a low- $Z$ one), when the electronic equilibrium comes at about $1.2 \mathrm{stu}$ (a high- $Z$ material) to about 1.5 (a low- $Z$ one). So the formation of the secondary radiation takes place in a tract comprising an accelerator's exit window, the converter and the electron stopper. Every of those devices, in its turn, includes the elements affecting on characteristics of the secondary radiation (the foils of the accelerator exit window and of the input window of the converter, its plates, the water filled gaps between them, etc.).

\section{CONFIGURATION OF ACCELERATOR'S EXIT DEVICES}

The study of the Compton DCD characteristics was conducted by means of computer simulation with the use of a transport code PENELOPE/2006 [7]. The calculations were carried out with due regard for the actual beam parameters of a LU-40 electron Linac of NSC KIPT [8]. The draft of the accelerator exit devices in a mode of the X-ray generation and its monitoring using DCD is given in Fig. 1.

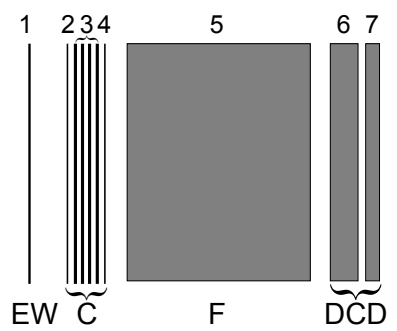

Fig. 1. Geometry of the accelerator exit devices

An electron beam passes through the exit window EW consisting of a Ti foil $50 \mu \mathrm{m}$ thick (it. 1). The as- 
sembly of the $\mathrm{X}$-ray converter $\mathrm{C}$ is positioned at a distance of $12 \mathrm{~mm}$ from the foil.

The converter comprises the input and output Ti-foils by $50 \mu \mathrm{m}$ in thickness (it. 2, 4), and also 4 Ta-plates each $1 \mathrm{~mm}$ thick (it.3) with the $1 \mathrm{~mm}$ spaces between them for cooling water. Followed the converter an electron filterstopper F corresponds a cylinder from aluminium. For every energy of the beam electrons, its height was determined to be in compliance with the total stopping length of $1.4 \mathrm{stu}$ for the $(\mathrm{EW}+\mathrm{C}+\mathrm{F})$ tract. In this case the formation of the dynamic equilibrium in the secondary radiation at the filter exit can be completed.

For better understanding of nature of the charge generation in DCD, the transversal size of the tract elements was considered as equal to $10 \mathrm{~cm}$ with the small distances between all devices. In this case their transversal size exceeds the width of the flux of the secondary radiation, and there no need to take into account the effect of a distance to converter on the detection process.

\section{FORMATION OF CHARGE IN DETECTOR}

The typical beam spectrum of the LU-40 accelerator with energy $E_{0}=40 \mathrm{MeV}$ in its peak is given in Fig. 2 . The average electron energy over the spectrum makes $38.54 \mathrm{MeV}$.

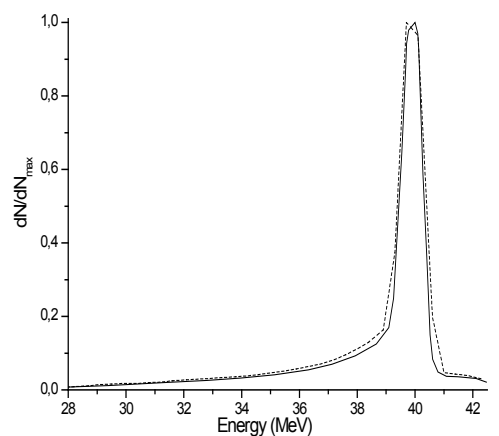

Fig. 2. Actual (solid curve) and simulated (dash curve) spectra of the beam
Fig. 3 demonstrates the results of the calculation of dependence of Al-filter height providing the stopping length of the tract of formation of the secondary radiation of $1.4 \mathrm{stu}$ on the electron energy $\mathrm{E}_{0}$. The characteristics of the radiation obtained in such a way at the filter exit and $\mathrm{E}_{0}=40 \mathrm{MeV}$, reduced to the unit of the average beam current, are given in Table 1.

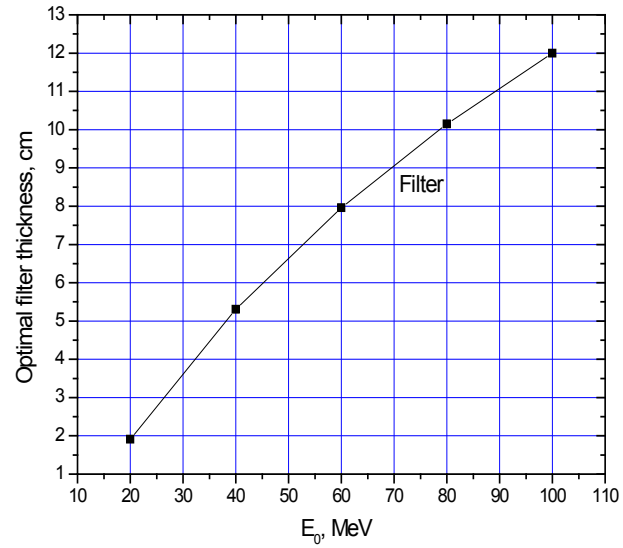

Fig. 3. Dependence of optimum height of the electron filter on initial electron energy

The data on the range of the secondary electrons and positrons, generated with braking radiation in a number of materials, are shown in Fig. 4. The results given hereafter are related to a chosen idealized configuration of the exit devices and a DCD made from copper. As the conducted study has shown, that material seems to be the most promising for such a type of the equipment. So in Fig. 5, the result of calculations of average energies $\mathrm{E}_{\mathrm{av}}$ of the secondary electrons, positrons and gammas induced in a copper plate in the direction of the primary radiation $\mathrm{E}_{\mathrm{av}}$ (transmitted particles), and also of the backscatter ones. The normalized spectra of those particles are given in Fig. 6.

Characteristics of the secondary particles at the detector input $\left(E_{0}=40 \mathrm{MeV}\right)$

\begin{tabular}{|c|c|c|c|c|c|}
\hline $\begin{array}{c}\text { Total power, } \\
\mathrm{kW} / \mathrm{mA}\end{array}$ & $\begin{array}{c}\text { Photons, } \\
\mathrm{kW} / \mathrm{mA}\end{array}$ & $\begin{array}{c}\text { Electrons, } \\
\mathrm{kW} / \mathrm{mA}\end{array}$ & $\begin{array}{c}\text { Positrons, } \\
\mathrm{kW} / \mathrm{mA}\end{array}$ & $\begin{array}{c}\text { Electron current, } \\
\mathrm{mkA} / \mathrm{mA}\end{array}$ & $\begin{array}{c}\text { Positron current, } \\
\mathrm{mkA} / \mathrm{mA}\end{array}$ \\
\hline $9.131 \pm 0.035$ & $8.805 \pm 0.036$ & $0.2398 \pm 0.0079$ & $0.0824 \pm 0.0049$ & $52.4 \pm 1.5$ & $12.42 \pm 0.58$ \\
\hline
\end{tabular}

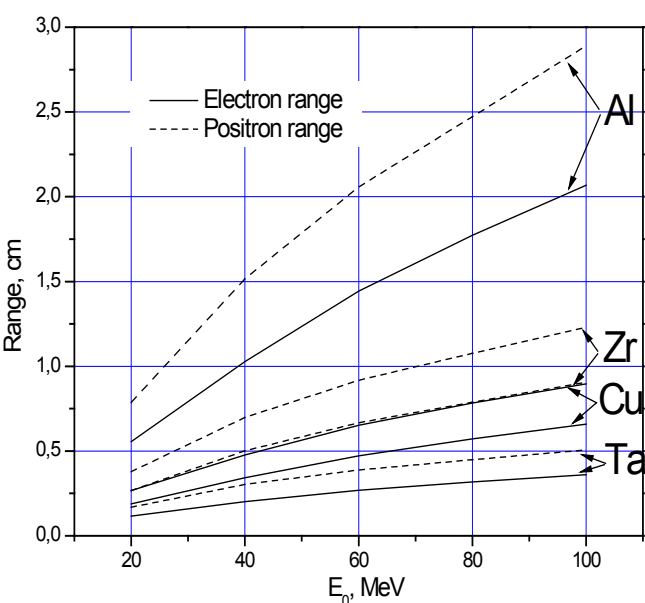

Fig. 4. Dependence of range of the secondary electrons and positrons in a set of materials on the energy of the primary electron beam 


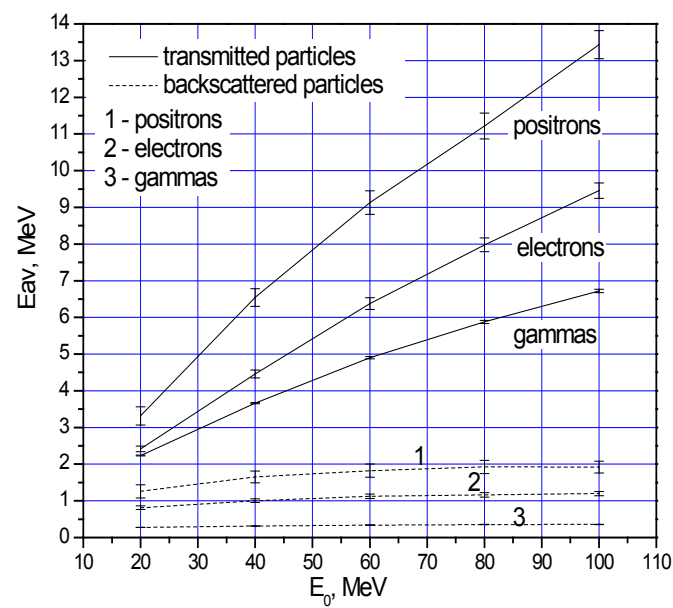

Fig. 5. Dependence of average energy of the secondary particles in copper on the electron energy in the primary beam
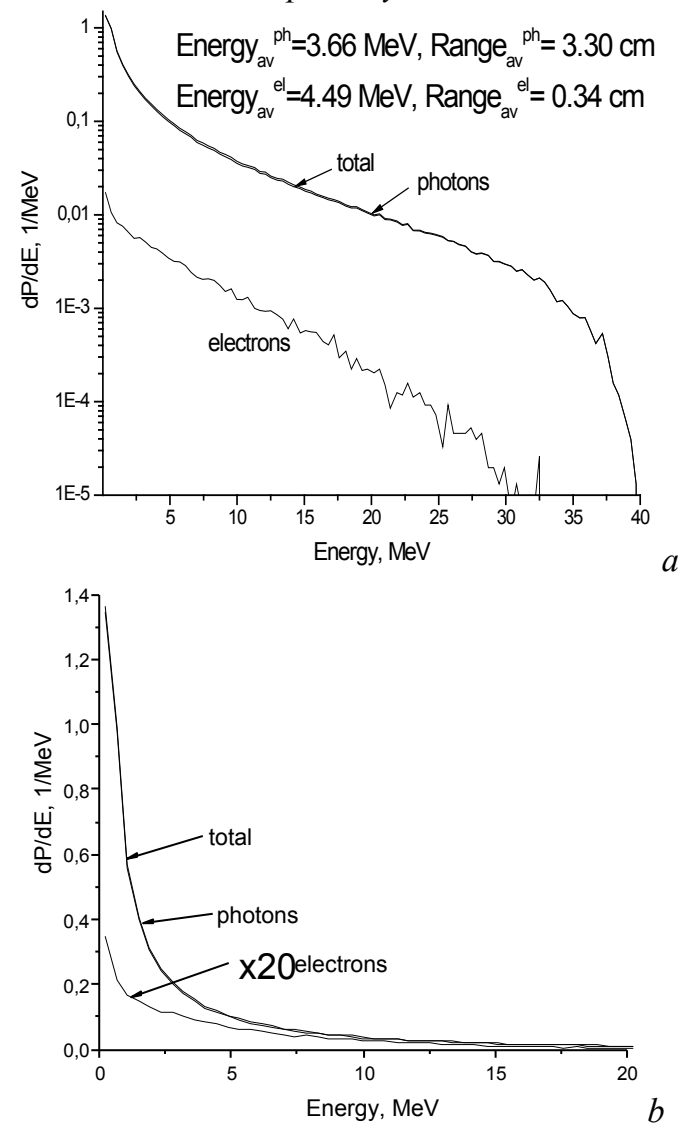

Puc. 6. Normalized spectra of the direct (a) and backscattered radiation (b) from copper plate $\left(E_{0}=40 \mathrm{MeV}\right)$

The dependence of the charge generated with the Xray radiation in a single copper plate on its thickness is presented in Fig. 7. It is seen, that at thickness increasing up to $20 \mathrm{~mm}$, the sign of its charge changes and the value grows.

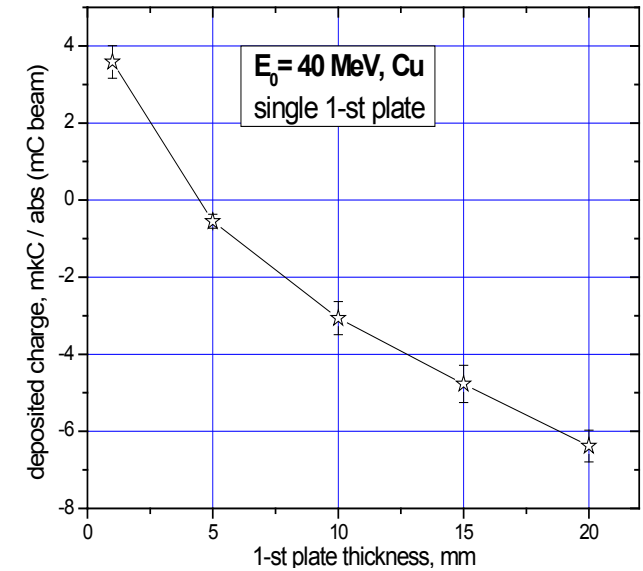

Fig. 7. Dependence of normalized deposited charge in a single copper plate on its thickness at action of dynamic equilibrium $X$-ray radiation

The results of calculation on the charges of DCD fabricated from two copper plates depending on the thickness of the first at a fixed thickness of the second $(1 \mathrm{~mm})$ are given in Fig. 8. It is evident, that the plates are oppositely charged. Under such conditions the negative charge in the first plate reaches maximum at its thickness of about $20 \mathrm{~mm}$. In the meanwhile, the positive charge of the thin plate changes faintly.

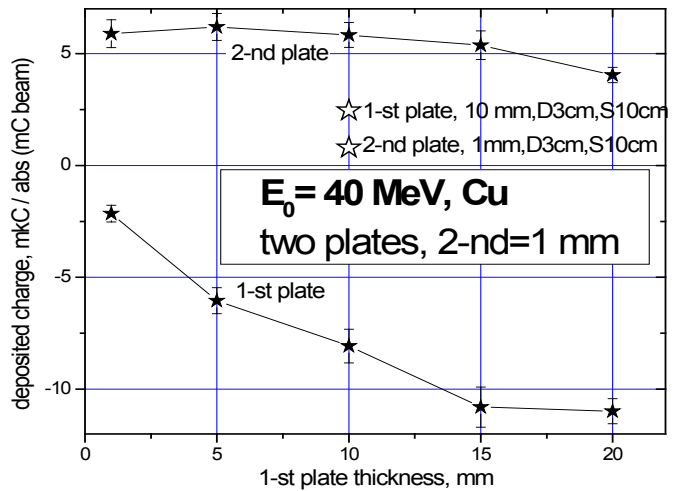

Fig. 8. Dependence of normalized charges generated with dynamic equilibrium $X$-ray radiation in the plates of DCD from copper on the thickness of the first plate $\left(E_{0}=40 \mathrm{MeV}\right)$

For comparison, the charges of the plates for the case when their diameter makes $3 \mathrm{~cm}$, the first is 10 and second $1 \mathrm{~mm}$ thick at a distance from the converter to DCD of $10 \mathrm{~cm}$, are calculated as well and denoted in Fig. 8 with the transparent asterisks. It is obvious, that the differential charge of the plates changes its sign, when its value (determinative the detector sensibility) decreases considerably.

For the DCD geometry providing maximum of the detector sensibility, its value was calculated as the dependence on $Z$ of the detector material (Fig. 9), and also the dependence of the copper DCD on the end-point energy of the bremsstrahlung radiation (Fig. 10). 


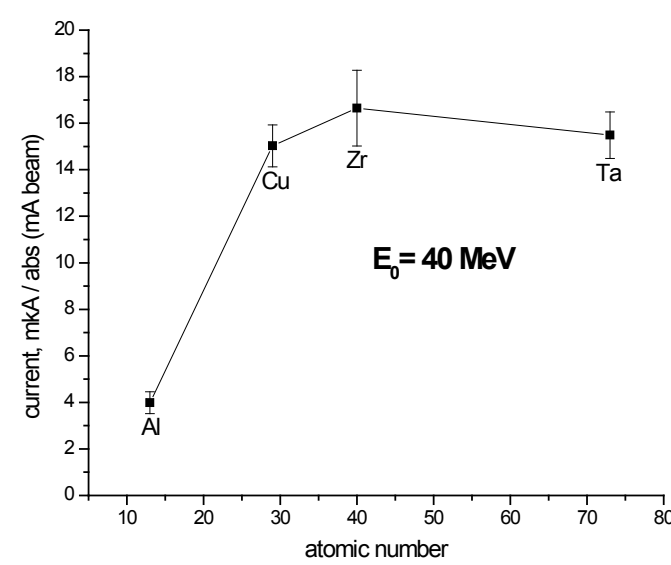

Fig. 9. Normalized differential beam between the plates of DCD depending on its material atomic number

\section{DISCUSSION}

At a stopping length of the tract of the secondary radiation formation of above $1.4 \mathrm{stu}$, the flux does not contain practically the electrons of a primary beam and consists only from the secondary particles. Under such conditions the photon component brings $96 \%$ of the secondary radiation power, 3 and $1 \%$ of the electron and positron ones respectively (see Table 1). The positron flux makes $\sim 25 \%$ of particles as compared with the electrons.

The key factors determinative charging of the Compton DCD are the fluxes of the electrons oncoming and outgoing the detector plates. A plate with thickness less than the average range of the secondary electrons should be considered as thin, while if the thickness exceeds the range, it is considered as thick. So for the DCD materials under study, the secondary electrons have the lowest range of $1.17 \mathrm{~mm}$ in tantalum at $\mathrm{E}_{0}=20 \mathrm{MeV}$. The maximum range of $2.07 \mathrm{~cm}$ takes place in aluminum at $\mathrm{E}_{0}=100 \mathrm{MeV}$. So a DCD plate by $1 \mathrm{~mm}$ in thickness can be considered as thin and one by $20 \mathrm{~mm}$ as thick in the all span of energy of the beam electrons under study.

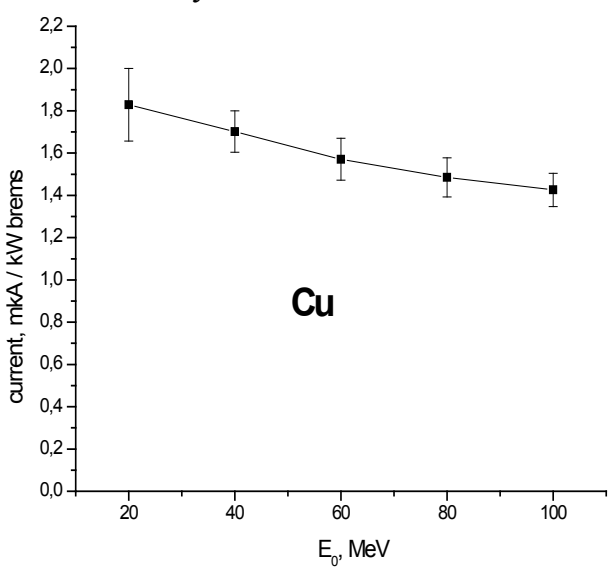

Fig. 10. Differential current between DCD plates depending on energy of primary beam electrons

An electron flux acting on first plate of a detector from side of second one changes its charge state as compared with the situation when the first plate is single. It is connected with the fact that the energy of those particles $(0.8 \ldots 1.2 \mathrm{MeV})$ is considerably less than the energy of the electrons moving onward (see Fig. 6). As it is evident from Fig. 8, at the presence of a second plate, the dependence of charge of the first plate on its thickness shifted in the lump into the negative side (see Fig. 7).

So a thin plate, being positioned last downstream the beam, is charged always positively and plays the role of an emitter. The mayor part of the electrons incident on it is not absorbed, and so not changes its charge state. At the same time, the photo- and Compton electrons, generated under exposure to high-energy photons, leave the plate forming the positive charge in it. In turn, the thick plate is always charged positively (see Figs. 7 and 8) because the mayor part of incident electrons stays in it. The opposite charge of the plates makes it possible to obtain a feed-free differential current in a detector's circuit.

\section{CONCLUSIONS}

A Compton DCD in the form of two parallel plates of different thickness can be used for monitoring of flux of high-energy bremsstrahlung photons. For the effective DCD application, the stopping length of formation of secondary radiation should be of about $1.4 \mathrm{stu}$. The maximum of the DCD sensitivity is provided with the plates of size exceeding the lateral dimension of a radiation flux, as well as when the thickness of the first plate (the collector) and of the second plate (the emitter) are of $\sim 20 \mathrm{~mm}$ and of $\sim 1 \mathrm{~mm}$, respectively.

The detector reveals a weak dependence of its sensitivity on the atomic number of the plate material at $Z>29$, and also on the end-point energy of the bremsstrahlung radiation in the range of 20 to $100 \mathrm{MeV}$.

For verification of previously noted results, an experiment was conducted at the LU-40 electron Linac (Fig. 11). The converter $\mathrm{C}$ was positioned at a distance of $2 \mathrm{~cm}$ from the exit window of the accelerator. The converter consists of 4 tantalum plates each by $1 \mathrm{~mm}$ in thickness separated with air gaps for cooling. The electron filter $\mathrm{F}$ (a cylinder from aluminum $50 \mathrm{~mm}$ high) was situated $15 \mathrm{~mm}$ downstream from the converter. Just behind the filter, a prototype of DCD was placed. It embraces a housing from stainless steel $5 \mathrm{~mm}$ thick with the two copper plates inside of 20 and $1.5 \mathrm{~mm}$ thick respectively with the $3 \mathrm{~mm}$ spacing. The flux of X-rays was entered through the input window (a $50 \mu \mathrm{m}$ titanium foil).

Before the exposure, the device was pumped out using a forepump. The signals from the plates were transmitted through the coaxial cables, registered with a digital oscilloscope Siglent SDS 1072 and recorded at an output medium. The uncertainty of determination of the signal amplitude was about $15 \%(\mathrm{k}=1)$.

The accelerator operated in a mode:

electron energy, $\mathrm{MeV} \quad 39$

pulse repetition rate, $\mathrm{Hz} \quad 50$;

pulse duration, $\mu \mathrm{s} \quad 1.5$.

The experimental results are given in Fig. 12 and Table 2. 


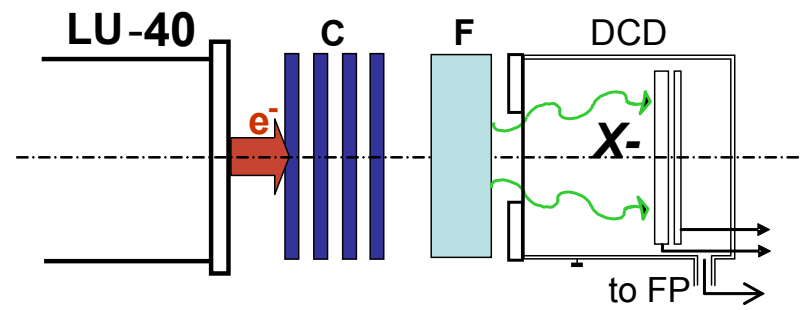

Fig. 11. Draftt of DCD prototype testing at LU-40 Linac

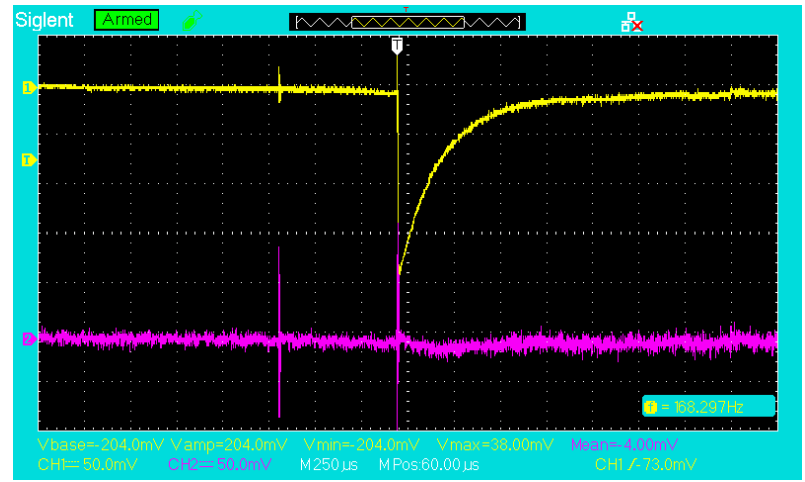

Fig. 12. Typical oscillogram of the DCD signals (the pulse beam current is $60 \mathrm{MA}$ ): upper sweep-the first plate, the lower sweep-the second plate

Table 2 Amplitude of differential signal from DCD plates

\begin{tabular}{|c|c|c|c|}
\hline Pulse beam current, $\mathrm{MA}$ & 40 & 50 & 60 \\
\hline Differential current, $\mu \mathrm{A}$ & 280 & 340 & 400 \\
\hline
\end{tabular}

REFERENCES
1. M.G. Mittelman, N.D. Rosenblum. Charge detectors of ionizing radiation. M.: "Energoizdat", 1982 (in Russian).

2. V.L. Uvarov, V.I. Nikiforov, V.A. Shevchenko, et al. Feed-free monitoring of intense high-energy bremsstrahlung // Proc. of EPAC 08. 2008, p. 13111313.

3. N.P. Dikiy, A.N. Dovbnya, V.L. Uvarov. Development of a New Electron Irradiation Based Technology for Technetium-99m Production // Proc. of the 6th Europ. Part. Accel. Conf. EPAC'98 (Stockholm, 1998) p. 88-90

4. Y. Gohar, J. Baily, H. Belch, et al. Acceleratordriven subcritical assembly: concept development and analyses // Proc. of the RERTR-2004 Int. Meet. www.iaea.org/inis/collection/.../Public/36/.../36069 552.pdf

5. Standard ISO/ASTM 51608. Standard Practice for Dosimetry in an X-ray (Bremsstrahlung) Facility for Radiation Processing.

6. V.I. Nikiforov, V.L. Uvarov. Analysis of mixed e,Xradiation along the extraction facilities of electron accelerators // Atomic Energy. 2009, v. 106, Iss. 4, p. 281-286.

7. F. Salvat, J.M. Fernandez-Varea, J. Sempau. PENELOPE-2006. A Code System for Monte-Carlo Simulation of Electron and Photon Transport. OECD Nuclear Energy Agecy, Issu-les Moulineous, France, 2006.

8. N.I. Ayzatsky, V.I. Beloglazov, V.P. Bozhko, et al. Electron $100 \mathrm{MeV}$ Linac Based Facility to NuclearPhysical Experimental Investigation // Problems of Atomic Science and Technology. Series "Nuclear Physics Investigations”. 2010, № 2, p. 18-22.

Article received 20.10.2019

\section{ОПТИМИЗАЦИЯ КОМПТОНОВСКОГО ДЕТЕКТОРА ПРЯМОГО ЗАРЯДА ДЛЯ МОНИТОРИНГА ВЫСОКОЭНЕРГЕТИЧНОГО ТОРМОЗНОГО ИЗЛУЧЕНИЯ}

\section{В.И. Никифоров, И.Н. Шляхов, В.А. Шевченко, А.Э. Тенишев, В.Л. Уваров}

Исследованы условия применения комптоновского детектора прямого заряда (ДПЗ) для мониторинга высокоэнергетического тормозного излучения. Описан метод расчета характеристик вторичного е,Хизлучения на выходе ускорителя электронов и обеспечения условия электронного равновесия. Методом компьютерного моделирования изучены процессы формирования зарядов в ДПЗ, состоящем из двух пластин разной толщины из различных металлов. На основе полученных результатов сформулированы требования к составу ДПЗ для обеспечения максимума его чувствительности. Показано, что в предложенной геометрии ДПЗ она слабо зависит от атомного номера его материала в области $Z>29$, а также от граничной энергии тормозного излучения в диапазоне $20 \ldots 100$ МэВ.

\section{ОПТИМІЗАЦІЯ КОМПТОНІВСЬКОГО ДЕТЕКТОРА ПРЯМОГО ЗАРЯДУ ДЛЯ МОНТТОРИНГУ ВИСОКОЕНЕРГЕТИЧНОГО ГАЛЬМІВНОГО ВИПРОМІНЕННЯ}

\section{В.І. Нікіфоров, І.М. Шляхов, В.А. Шевченко, А.Е. Тєнішев, В.Л. Уваров}

Досліджені умови застосування комптонівського ДПЗ для моніторингу високоенергетичного гальмівного випромінювання. Описаний метод розрахунку характеристик вторинного е,Х-випроміннюваня на виході прискорювача електронів, а також забезпечення умови електронної рівноваги. Методом комп'ютерного моделювання вивчені процеси формування зарядів у детекторі, що складається з двох пластин різної товщини 3 різних металів. На основі отриманих результатів сформовані вимоги до складу ДПЗ для забезпечення максимуму його чутливості. Показано, що у запропонованій геометрії ДПЗ вона слабо залежить від атомного номера матеріалу в області Z > 29 і граничної енергії гальмівного випромінювання в діапазоні $20 \ldots 100 \mathrm{MeB}$. 